\title{
Urban Transformation in the Context of Rail Transport Development: The Case of a Newly Built Railway Line in Gdańsk (Poland)
}

\author{
Marcin Połom (D), Maciej Tarkowski (D), and Krystian Puzdrakiewicz (D) \\ Department of Regional Development Geography, Institute of Geography, University of Gdańsk, Poland \\ Correspondence should be addressed to Marcin Połom; marcin.polom@ug.edu.pl
}

Received 2 June 2018; Revised 20 September 2018; Accepted 1 October 2018; Published 29 October 2018

Guest Editor: Borna Abramović

Copyright (C) 2018 Marcin Połom et al. This is an open access article distributed under the Creative Commons Attribution License, which permits unrestricted use, distribution, and reproduction in any medium, provided the original work is properly cited.

\begin{abstract}
Development of railway transport systems is perceived as one of the most effective ways of shaping sustainable urban transportation. However, railway transportation systems can only compete with individual means of transportation when having properly developed infrastructure, especially in terms of the train stops accessibility. The main objective of this article is to discuss mutual relations between operation of a newly built railway line and spatial changes taking place in its closest vicinity which determine the accessibility to it. The research methods included the GIS tools, direct measurements of passenger exchange, and public opinion poll among the passengers taking the new line. The research area was the city of Gdańsk, one of the largest cities in Poland, where transportation problems are cumulating as a result of the urban sprawl. The new railway was opened in order to mitigate these problems. The research results have proved this strategy was only partially successful as the course of the line and location of the stops do not provide a large number of potential passengers. That is why it was necessary to connect the line to the already existing urban transportation system, yet this solution has not resolved the problem completely. However, the urban development plan assumes introduction of large housing projects in the areas surrounding the existing train stops what will allow using the new line more efficiently in the future.
\end{abstract}

\section{Introduction}

Transport is regarded as a basic factor fostering development of urban regions [1-3]. The "triumph of the city" [4] will not be possible without an efficient transportation system, urbanisation, although in some regions it is not as dynamic as it used to be in the demographic aspect, it is still progressing in the economic, social, and spatial dimension. The structure of urban transportation systems is subject to ongoing changes. Pedestrian traffic and public transport are considered to no longer have a dominant position in the system; motorised individual transport is now the most important part of it. The external costs of such a model (including costs of accidents, air pollution, climate change, noise, and congestion) [5] have forced search and implementation of solutions aimed at supporting pedestrian traffic, improving public transportation systems and promoting alternative ways of individual transport (private bicycles, urban bicycles, car-sharing systems, and all kinds of electric individual means of transport). Although, obviously, technological progress was the main force driving the abovementioned changes [6], yet some social phenomena were also fostering them, such as emergence of the automobility culture [7] and the concept of sustainable mobility, aimed at overthrowing the car culture. In order to introduce the idea of sustainable mobility, actions in four basic dimensions have to be taken: implementing the latest technology to increase the efficiency, developing a pricing policy which internalises the external costs generated by each and every mode of transport, introducing spatial management tools aimed at decreasing in demand for transport and bringing about a change in the modal split, and providing a precisely addressed information system for citizens [8].

One way of bringing the idea of urban sustainable mobility into life is to develop rail-based public transportation systems, including urban railways. Such systems allow increasing efficiency of transport in two ways: through technical improvement of infrastructure and vehicles and, 


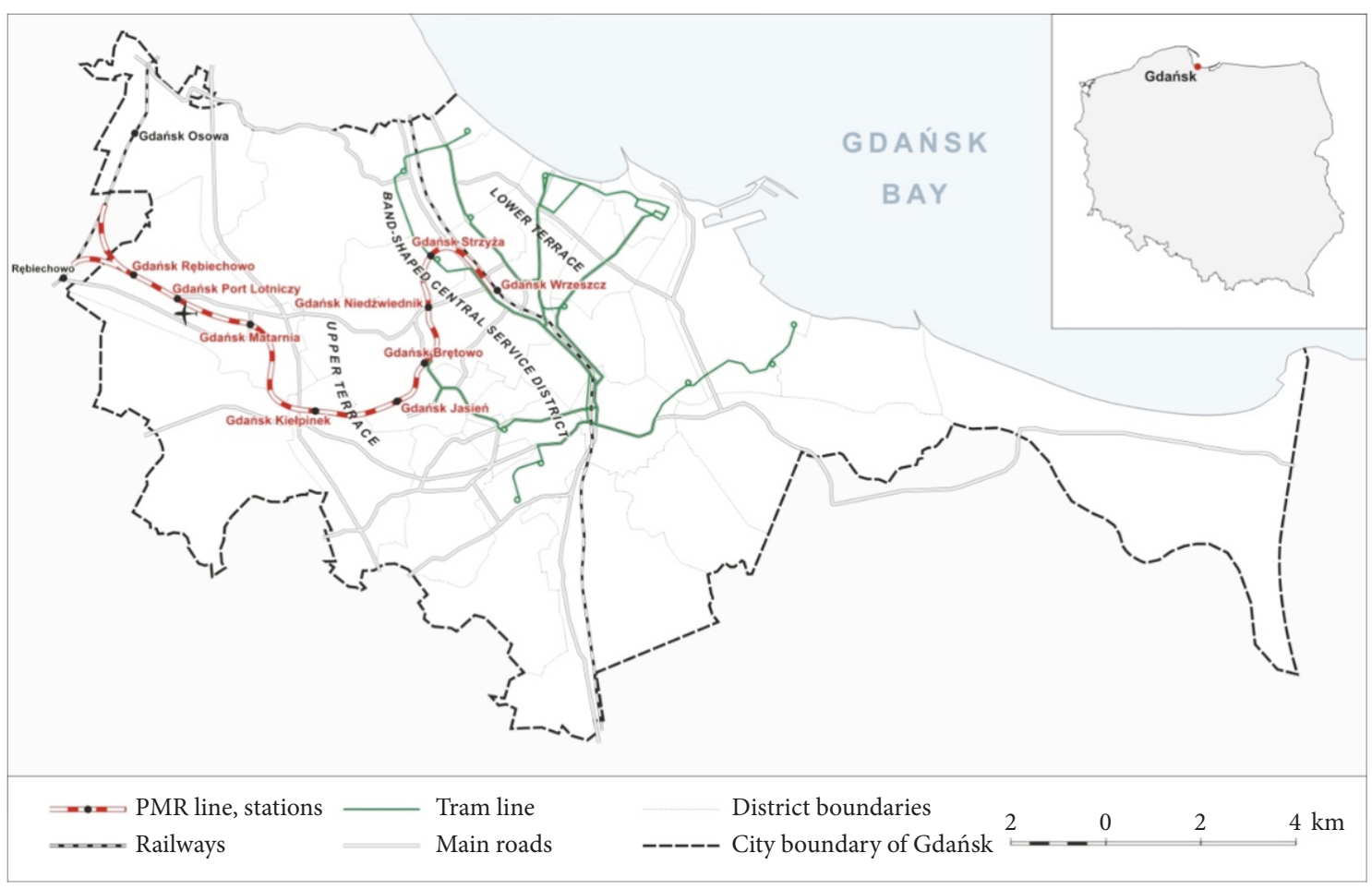

Figure 1: The Pomeranian Metropolitan Railway line within the city of Gdańsk boundaries.

above all, through introducing a change in the modal split which limits use of private cars and reduces congestion and its all negative consequences, including the social ones [9]. This change is also vital in the context of reducing greenhouse gas emissions [10]. Everyday functioning of cities and transportation systems is extremely energy-consuming; that is why the potential of reducing the emissions is so high in this case. However, these benefits can only be achieved when development of public rail-based transport systems is coupled with proper spatial planning. Hence, railbased transport plays a valuable role in shaping the spatialfunctional structure of cities [11, 12].

In the postsocial countries, including Poland, the presented above sequence of transformations took place much later. The system transformation towards the free-market capitalism (after 1989) covered both transportation and city management, to some extent. Not sufficient, in relation to actual demand, expenditures on the public transport infrastructure led to its degradation. Only some components of the system have been privatised, often with foreign capital participation, yet it has not improved the transport offer on a national level [13]. The rest of it, especially local commuter bus and train lines, have been gradually dismantled. This regression in the number of local lines was one of the main reasons for the decrease in the rail passenger traffic [14]. According to the data published by the Central Statistical Office, in 2000 the number of rail passengers in Poland constituted only $48 \%$ of the number recorded in 1990 and the number of bus passengers, $60 \%$. At the same time, the number of private cars constituted $189 \%$ of the number recorded at the beginning of the analysed decade [15]. A significant increase in the level of motorisation was not only a result of the regression in the public transportation services. Owning a car was a factor shaping the way of life and it served as a status symbol [16]. During the next decade after the beginning of the transformation (2000-2010) there were no significant changes in the structure of the above-mentioned modes. Accession to the European Union in 2004 allowed using the Structural Funds for development and modernisation of the transport infrastructure. Some of the money was set aside for development of urban road networks, what made it possible to reduce the traffic congestion in large cities, at least temporarily [17]. There were also some funds allocated for development of railways, including urban ones, but the scale of investment was less significant. Railway systems of Warsaw, Gdańsk-Gdynia-Sopot, Lodz, and Cracow were modernised at that time [18].

The main objective of this article is to answer a question to what extent launching the Pomeranian Metropolitan Railway has contributed to changes in the spatial and functional structure of Gdańsk, one of the largest cities in Poland (see Figure 1). E. Babalik [19] arguments the urban form of cities can influence the success of urban rail systems. It was observed that the economic vitality of central business districts, the location of employment and retail outlets, the population and residential density, and the dominant urban pattern were particularly important. Taking the strategic value of this investment under consideration, the authors will also make an attempt to indicate possible directions of spatial development of the city during the next decade. Transportation systems affect the process of spatial and functional urban structure shaping. That is why, in this article, 
a case of the Pomeranian Metropolitan Railway and the way it influences the urban structure of Gdańsk will be described, along with the mobility patterns of its citizens.

Despite the fact that the Pomeranian Metropolitan Railway serves other towns in the region, the spatial scope of this article is limited to the city of Gdańsk, where the main investment efforts were concentrated. Special attention was paid to the areas located in the closest vicinity of the PMR stations as the most notable changes in the spatial and functional urban structure can be observed there. The areas are planned to undergo some far-reaching changes in terms of spatial development. The time scope of the analysis was three years of the PMR operation, that is, from mid-2015 to mid2018. However, the future plans for further development of the Pomeranian Metropolitan Railway as well as provisions of the spatial development plan for Gdańsk have also been analysed [20].

The article consists of four parts. The first one comprises general background information on the case study, including information on the investment circumstances, the course of the route, location of the stations, and the size of passenger flows. In the second part the authors indicate the research methods and sources of the data used for analysis. The results have been presented with attention paid to four major issues: the existing land use patterns, population density, the degree of linkage between the PMR and the bus and tram systems, and expected changes in the land use. The article is completed with conclusions and recommendation concerning further research tasks.

\section{Case Study}

2.1. Unsustainable Mobility: Gdańsk as Typical Case of Polish Large City. Gdańsk is the sixth largest city in Poland with a population of approximately 464 thousand people (2016). Along with Gdynia and Sopot the three cities comprise a band-shaped spatial layout of a polycentric structure, which emerged as a result of many interrelated environmental, social, economic, and political conditions. It is a centre of a large urban region with a population of approximately 1 million people. According to the typology of functional urban areas created on the basis of their size, competitiveness, knowledge sources, and their accessibility [22], this region belongs to Type 4 European metropolitan areas as well as Szczecin, Poznan, Wroclaw, Lodz, Cracow, and Katowice (in Poland) and Cork in Ireland, Southampton (along with Bournemouth and Portsmouth) in Great Britain, Porto in Portugal, Seville in Spain, Havre and Bordeaux in France, Genoa in Italy, Valletta in Malta, Turku in Finland, Tallinn in Estonia, Riga in Latvia, Vilnius in Lithuania, Bucharest and Timisoara in Romania, Sofia in Bulgaria, and Ljubljana in Slovenia. Gdańsk, as well as other large Polish cities, faces the problem of unsustainable mobility. According to Gdańsk Traffic Research [23], the share of individual transport is $41 \%$ and it significantly exceeds shares of other forms of mobility. However, such a structure of urban traffic is not something unusual; it is commonly observed in other Polish and European cities. There are also cities with a higher share of individual transport yet it does not change the fact that the modal split of transport based on individual means of transportation causes a number of essential problems in terms of functioning of cities and everyday life of their citizens. One of the most recognisable one is traffic congestion. As it has already been mentioned, this phenomenon has been developing in Poland since the beginning of the political transformation and nowadays it has reached the level observed in the highly developed countries. Not only was it a result of a general improvement of the citizens' wealth, but also it is connected with chaotic development of suburbanisation.

2.2. Local Context of Urban Mobility in Gdańsk. All the above-mentioned general problems affect Gdańsk, yet there are some local factors influencing the situation, too. The environmental conditions were the main reason why the city has band-shaped infrastructural systems serving two relatively separated parts of the city: the lower terrace, located mostly on an alluvial plain (northern and eastern parts of Gdańsk) and the upper terrace, located at 100-150 m above sea level, on a postglacial upland (southwestern and western parts of Gdańsk). On the lower terrace there is a historical city centre, band-shaped central service district, port and industrial areas, and residential districts with high population densities. On the upper terrace there are mainly scattered residential areas of lower population densities. They generate problems for public transportation system and are not as well communicated as the central ones. On the upper terrace there are also several other objects generating traffic: the airport with an industrial district nearby and some large shopping centres. A steep edge of the upland is a natural boundary separating the two parts of the city. It is covered with forest and it is legally protected. As seen from the perspective of urban development, this barrier was overcome in the 1970s and 1980s when large-panel prefabricated housing estates were built. The process of inhabiting the upper terrace was continued during the period of transformation. It showed signs of chaotic internal suburbanisation [24]; there were both detached houses built by the owners themselves and large residential areas constructed by developers. Such a suburbanisation model makes it difficult to make urban mobility sustainable. Modernisation and development of the road system on the upper terrace began too late and its pace was not sufficient. As for the public transport infrastructure, the situation was even worse and it did not contribute to a decrease in the share of citizens using private cars. On the contrary, the role of this means of transport increased by $2 \%$ when compared with 2009; the city has not been moving towards the sustainable mobility model [23]. However, some adverse trends had been noticed before that and they triggered an intense public debate regarding further transport investments in the city. The conclusions of this debate were included in the Gdańsk 2030 Plus Development Strategy [25]. As for transport and mobility it was stated that the modal split of transport in the city has to be changed in order to meet the criteria of sustainable mobility. The Pomeranian Metropolitan Railway had already been under construction at that time and it was considered a logical component of this plan. 
2.3. Towards More Sustainable Mobility: Pomeranian Metropolitan Railway. Construction of an agglomeration railway line in the urban area of Gdańsk-Gdynia-Sopot has been planned for several decades. It was assumed that the railway line would connect the city centres of Gdańsk and Gdynia with the existing airport in Gdańsk and the planned one in Gdynia-Kosakowo. It was planned to extend the offer of the Fast Urban Railway running along the central service district. Initially, it was assumed that the PMR would start operation before the 2012 UEFA European Championship, but it was not possible to meet the deadline. It took three more years to complete the construction. The Pomeranian Metropolitan Railway is a name for the line itself and for a special purpose company established to construct and then manage the railway line. The line was constructed between 2013 and 2015, financed mainly from the structural EU funds. Although it was built along an old railway line, which was there in the past, the whole infrastructure had to be reconstructed. That is why this investment is of special meaning as there was no other urban region where the scale of construction and modernisation of a railway line was that large.

As part of the investment, a railway line $(19,5 \mathrm{~km})$, including $18 \mathrm{~km}$ of a double track section towards GdańskOsowa station and a connector $(1,5 \mathrm{~km})$, was constructed. Additionally, eight new stations were built and two more already existing ones were modernised to connect the PMR with the Fast Urban Railway. The maximum permissible speed on this route is $120 \mathrm{~km} / \mathrm{h}$.

Right after launching the PMR the line Gdańsk GłównyGdańsk Airport-Gdynia Główna started to operate as well as two shorter lines to Gdańsk Osowa and Gdańsk Wrzeszcz. Then, in the period of 2015-2016 other two lines were opened connecting Gdańsk with two smaller towns located outside the urban area. However, in this article, the main focus will be put on the lines located within the city of Gdańsk boundaries.

A relatively short, three-year period of the PMR operation, during which there were numerous changes in the timetable as well as a temporary cessation of operations due to extremely heavy rain in July and August 2016, does not allow unambiguously evaluating the investment. An actual impact of the Pomeranian Metropolitan Railway on the urban traffic may be assessed by analysing the number of its passengers (Figure 2). In the period of October 2015-March 2018 a visible positive trend is observed when analysing the total number of passengers. However, when analysing the number of passengers using not only the innercity lines, but also the ones connecting Tricity with Kartuzy and Kościerzyna, some interesting patterns can be observed. According to the PKM S.A. (PMR limited company) data, the number of passengers taking part in the metropolitan traffic (Gdańsk and Gdynia) actually decreased from 151,6 thousand in June 2016 to 141,1 thousand in June 2017. Most probably, thanks to modifications in the timetable it was possible to reverse this negative trend and in March 2018 the number of passengers reached approximately 190 thousands.

The results of a direct measurement carried out in the period of October-November 2017 [21] have shown that the most popular stations in Gdańsk are Wrzeszcz, Strzyża, and Jasień. Airport and Kiełpinek are also among the stations of

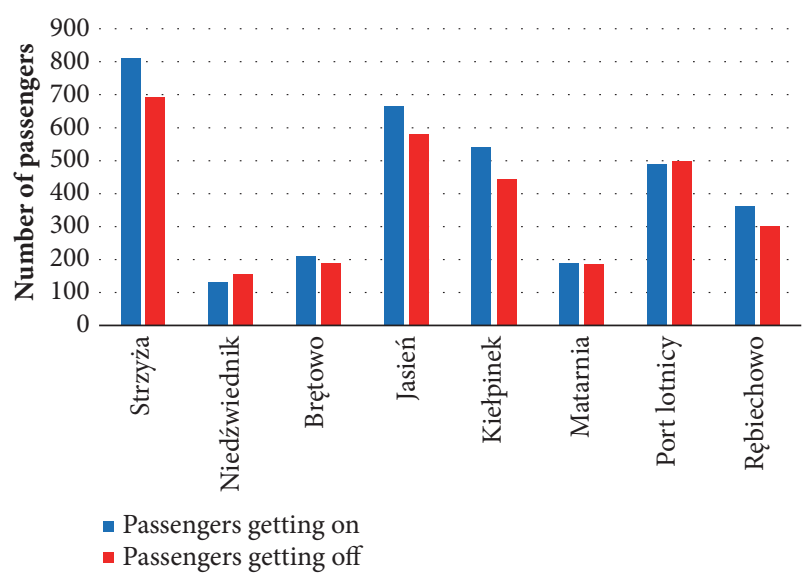

FIgURE 2: Average daily number of getting on and getting off passengers by the PMR line stations in the period of 17.10-16.11.2017. Source: own elaboration based on [21].

significant importance. The least popular among the PKR passengers is Niedźwiednik station. It is situated relatively close to the central service district and it is more convenient for the citizens to reach it by bus.

\section{Methods and Data}

In order to achieve the objective of this article the authors used a whole range of GIS tools; they carried out direct measurements of the passengers flow and they interviewed the passengers using the PMR service.

3.1. GIS Tools. The GIS tools (QGIS software) were used while determining spatial conditions along the railway line, location of the stations, and how they are connected by bus and tram. The GIS tools were also useful when describing the foreseen changes in the land use. The base for their implementation was a map of topographic objects at 1:10 000 scale obtained from a publicly accessible cartographic resource base.

In order to assess the land use character and intensity of development in the closest vicinity of the stations, a tool named "fixed width buffer" was used. It allowed delimiting a $660 \mathrm{~m}$ equidistant for a 10 minutes' walking distance and a $1320 \mathrm{~m}$ equidistant for a 20 minutes' walking distance to the stations being central points of the delimited zones (Figure 3). The $660 \mathrm{~m}$ equidistant was also used to delimit the zones of 10 minutes' walking distance to the bus or tram stops which allow reaching a given PMR station within 5 minutes. In the literature normal walking speed varies from $3,2 \mathrm{~km} / \mathrm{h}$ to $5,4 \mathrm{~km} / \mathrm{h}$ and $4,5 \mathrm{~h} / \mathrm{km}$ on average [26]. In order to calculate the distance to the PMR station, which passengers have to cover in the 10- and 20-minute zones, the average normal walking speed of $4 \mathrm{~km} / \mathrm{h}$ was adopted [27-29], taking the space resistance resulting from implementation of the straight-line mechanism under consideration.

Time distances between the stations were calculated on the basis of public transport schemes and timetables for buses and trams published by the urban transport operator. This 


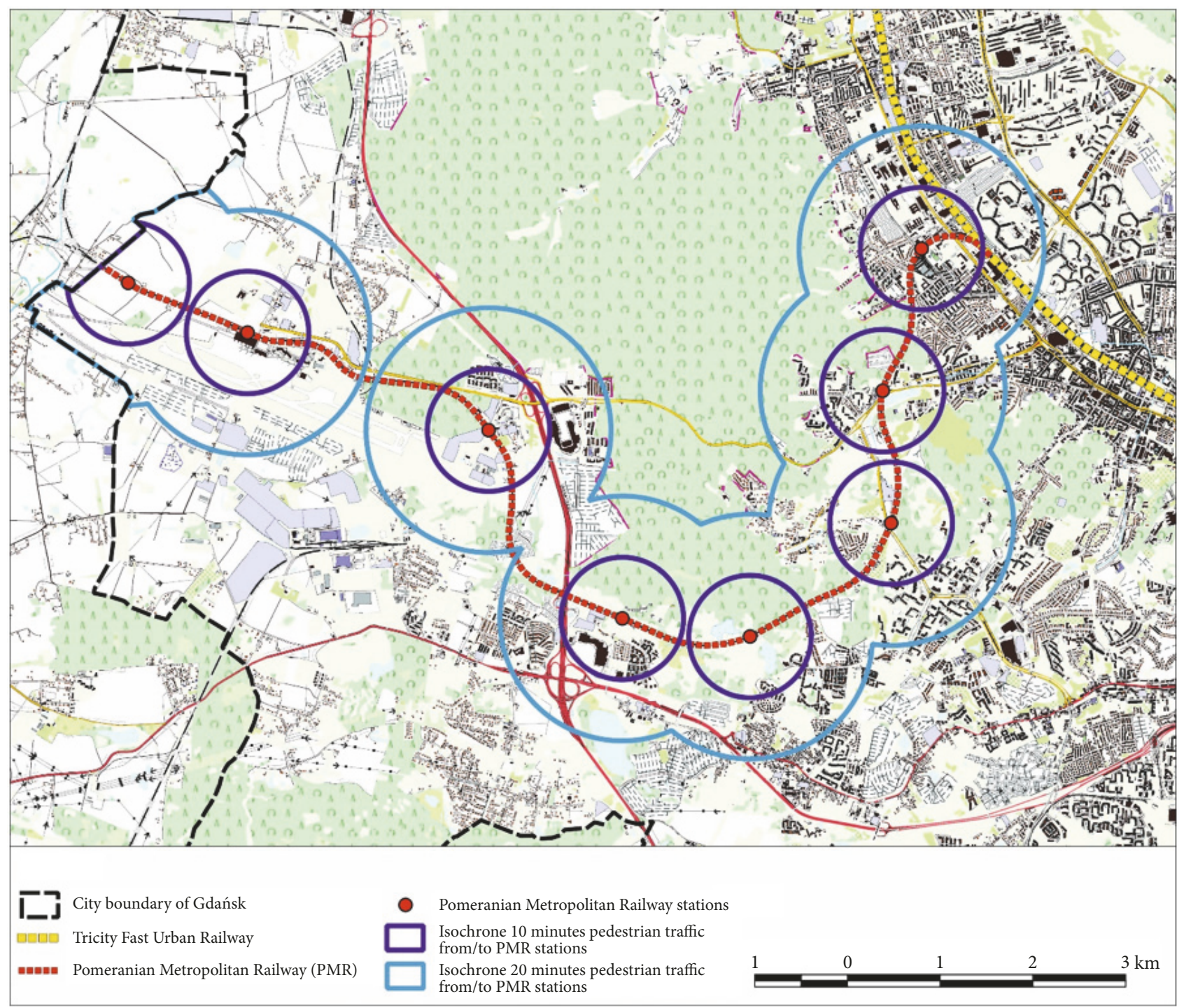

FIgURE 3: Zones of 10-minute and 20-minute walking accessibility to the PMR line in the context of the contemporary land use forms.

procedure allowed delimiting an indicative intermodal which is served by the PMR, buses, and trams (Figure 6). Intensity of communication linkages between the railway stations and bus/tram stops was depicted with the use of a ribbon-like cartogram. It was created on the basis of the timetables, taking the average number of all 5-minute daytime bus and tram courses to/from the railway stations on weekdays during a school year (both directions) (Figure 6). In order to assess the character and intensity of land use in the whole area served by the PMR, the authors analysed population density grids ( 100 $\mathrm{m} / \mathrm{lha}$ ). The most recent data on number of people registered in the city of Gdańsk at the end of 2016 was obtained from Gdańsk Development Office, local authority responsible for the spatial policy. In Poland it is obligatory for all citizens to register. However, there are no sanctions forcing people to do so. The majority of population actually lives in places where they are registered yet the number of people who do not is still growing. In 2009 the data regarding the number of registered people was officially published for the last time; in Gdańsk it was lower by 1,1\% than the number assessed using the balance sheet method. Using the above-mentioned data, the number of people having access to each railway station, the number of people living in common areas of the 1320 equidistant zones, and the total sum for all the stations were calculated. When calculating, rectangles having their geometrical centres within a zone set by a particular equidistant delimited for each of the station (Figure 5) were taken under consideration. Additionally, in order to assess the current land use structure as well as the planned changes in it, cartographic data included in the general local development plan for Gdańsk was used [8]. On the maps, being attachments to the plan, dominating land use forms, housing and housing-service areas as well as the foreseen changes in the land use are presented (Figure 7).

\subsection{Passenger Traffic Measurement and Questionnaire Sur-} $v e y$. In order to assess the volume of passenger traffic at every PMR station and the impact that the PMR exerts 
TABLE 1: Land use forms in the closest vicinity of (660 m radius) the PMR stations in Gdańsk (at the end of July 2017.

\begin{tabular}{|c|c|c|c|c|}
\hline Station & $\begin{array}{l}\text { Dominating housing } \\
\text { development type }\end{array}$ & $\begin{array}{c}\text { Dominating land-use forms } \\
\text { - housing and } \\
\text { housing-services (ha) }\end{array}$ & $\begin{array}{l}\text { Dominating supra-local } \\
\text { service or industrial } \\
\text { functions }\end{array}$ & $\begin{array}{l}\text { Elements integrating the } \\
\text { station with other modes of } \\
\text { transport }\end{array}$ \\
\hline Strzyża & $\begin{array}{l}\text { mixed with a domination of } \\
\text { single-house }\end{array}$ & 39 & $\begin{array}{l}\text { university campus, tram } \\
\text { depot, shopping centre, } \\
\text { sports centre, car } \\
\text { showrooms, }\end{array}$ & $\begin{array}{l}\text { tram stop at the depot and } \\
\text { a regular tram stop }\end{array}$ \\
\hline Niedźwiednik & multi-house & 28 & $\begin{array}{l}\text { asylum, cemetery, } \\
\text { non-public schools }\end{array}$ & bus stop \\
\hline Brętowo & mixed & 40 & & $\begin{array}{c}\text { terminal tram stop and a } \\
\text { bus stop }\end{array}$ \\
\hline Jasień & multi-house & 14 & & terminal bus stop, car park \\
\hline Kiełpinek & $\begin{array}{l}\text { mixed with a domination of } \\
\text { multi-house }\end{array}$ & 17 & shopping centre & terminal bus stop, car park \\
\hline Matarnia & multi-house & 11 & $\begin{array}{l}\text { service and industrial } \\
\text { companies }\end{array}$ & bus stop, car park \\
\hline Port Lotniczy & scattered single-house & 3 & office buildings, hotel & airport, terminal bus stop \\
\hline Rębiechowo & scattered single-house & 3 & arable lands & \\
\hline
\end{tabular}

Source: own elaboration based on the GIS analysis and fieldwork.

on mobility patterns, data on the volume of the passenger traffic was used [21]. The data was obtained during the 17.10.2017-16.11.2017 measurements carried out on typical weekdays in two sessions (6:00-9:00 and 14:00-19:00). For three selected stations 16-hour measurement was carried out. The measuring staff encompassed well-trained observers equipped with measuring cards, documents with a detailed description of the measurement, visibility vests, and name badges. Moreover, the passengers were being interviewed with the use of a standardised questionnaire. They were asked about motives behind and frequency of their journeys, why they choose the PMR, how they get to a starting station, and how they continue their journey after getting off the train. Usually, there were from 1 to 3 interviewers on each station, depending on where a given station is situated and the estimated number of passengers using it. The report summarising this measurement is publicly accessible and it was obtained from the Pomeranian Regional Planning Office which had commissioned the research. The office is regional authority responsible for the spatial policy.

\section{Results and Discussion}

4.1. Land Use Zones in the Areas Surrounding the PMR Line. The main problem connected with reconstructing an old railway line is the fact that the areas it used to cover have been built-up and now they are potential sources of passenger traffic. This is also the issue affecting the Pomeranian Metropolitan Railway line. Only two stations, Wrzeszcz and Strzyża, located on the lower terrace within the central service district are situated in a highly urbanised area with welldeveloped housing, service, and communication functions (Table 1). Other two stations, Niedźwiednik and Brętowo, are located in the upland edge; thus there are not many housing or service areas in their closest vicinity, yet still within the range of the $660 \mathrm{~m}$ zone. In most cases, in order to reach the station people have to walk up/down a steep hill what may discourage them from using the PMR trains.

There are five stations located in the upper terrace. The closest vicinity of three of them, Jasień, Kiełpinek, and Rębiechowo, is not densely built-up. In the areas around Jasień and Kiełpinek new housing estates are being constructed; some of them have already been finished. The areas around Kiełpinek station are the most densely built-up. There is a large housing estate there and a large shopping centre. However, the station is not located in the centre of this area so it is not attractive for all its residents. The least densely builtup areas surround Rębiechowo station (Table 1, Figure 3); they are mainly arable lands and areas with highly dispersed single-housing development; additionally, most of it is not located within the city boundary. The station is located near the city boundary in Banino, a village being now under a severe suburbanisation pressure.

The areas surrounding Matarnia and Port Lotniczy stations are more densely built-up than the closest vicinity of the three previously described stations. Matarnia station is located on the edge of a large industrial district and a housing estate. Such a peripheral location of this station marginalises its role in transport services. The second station (Port Lotniczy) is located near the airport which is a key object for this railway line. Improving accessibility of the airport was one of the motives behind the construction of the PMR line. What is more, in this area there are airport car parks, a hotel, and some objects situated on the edge of an office district, which core, in a form of the "Intel" headquarters, is not in the zone of convenient accessibility to the station.

The analysis of the land use of areas surrounding the PMR stations has confirmed a strategic character of this investment. It may be stated that it partially exceeds the foreseen demand what is a rare situation in Poland. However, the true future role of the PMR will depend on the housing estates 


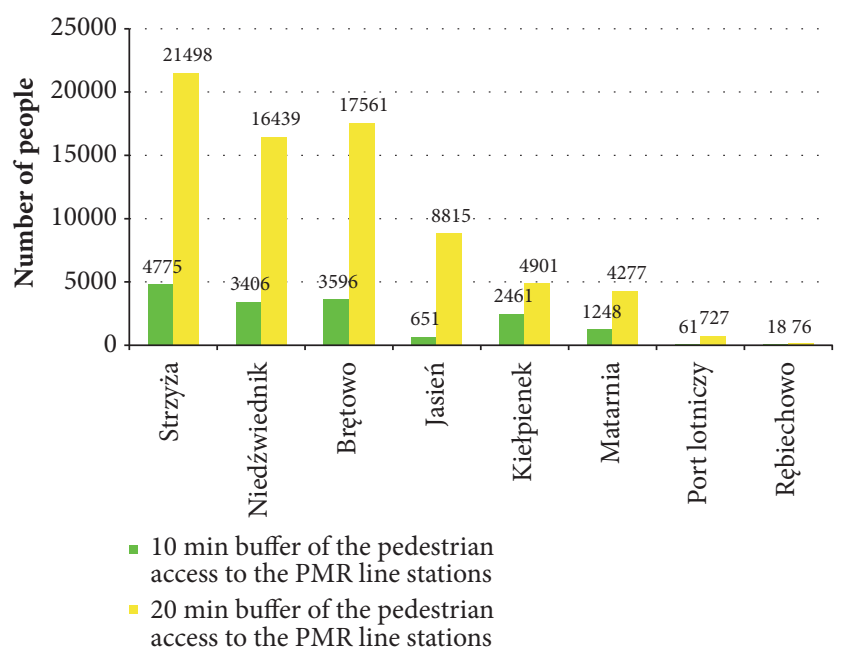

FIgUre 4: Population density in the zones of 10-minute and 20minute walking accessibility to the PMR stations.

development, organisation of bus and tram transportation systems, and their coordination as well as on development of the park and ride system in the vicinity of the line.

4.2. Population Density in the PMR Line Impact Zone. Spatial distribution of population is a consequence of the abovedescribed course of the PMR line and the intensity of land use. Population density is a vital factor affecting the level of its success, the success understood as a volume of passenger traffic [30]. For the purposes of this study, population densities for the 10 -minute $(660 \mathrm{~m})$ and 20 -minute $(1320 \mathrm{~m})$ walking accessibility zones have been calculated using the registration data. Areas located nearer to the Pomeranian Metropolitan Railway stations have low population densities reaching 15 people per 1 ha on average. The population densities vary from $0,16 \mathrm{ppl} / \mathrm{ha}$ for Rębiechowo station to $34 \mathrm{ppl} /$ ha for Strzyża station. The highest number of people living within the 10 -minute $(660 \mathrm{~m})$ and 20 -minute $(1320 \mathrm{~m})$ walking accessibility zones was recorded for Strzyża station, 4,8 thousands and 21,5 thousands, respectively. The lowest number for Rębiechowo station was only 18 and 76 people, respectively (see Figures 4 and 5).

Population density in the Pomeranian Metropolitan Railway impact zone is relatively low. The line has been located on the edge between some green areas (the landscape park) and new housing estates where developers started constructing buildings during the last decade. As an effect, the largest impact on effectiveness of the PMR line should be exerted by redirecting the vehicles of public urban transport to serve the railway stations in a formula of the multimodal transport (In the article the term "multimodal transport system" refers to a partially integrated transport system as the system in the city of Gdańsk is not fully integrated. There is no one official body managing all different transport subsystems. There is only a partially integrated fee system. Among the main tasks related to exploitation of the PMR line is integrating the public urban transportation system in Gdańsk and the PMR stations. Such actions refer to the idea of multimodal transport. In the literature, the issues of multimodality in everyday commuting have not been frequently addressed so far [31]. In a review article entitled Rail and Multimodal Transport[32] there are eighteen definitions, but only two of them refer to passenger transport. In both cases, by W. Jones et al. [33], it is defined as using two or more means of transport during one integrated journey. In passenger transport, the level of multimodality depends less on accessibility of alternative transport links, yet more on the quality of them, including presence of interchanges. In the literature, this quality is known as interconnectivity [[31] after: [34-36]]. Strategic documents issued by the European Union similarly define the way of organising urban transportation systems. In the White Paper "Roadmap to a Single European Transport Area-Towards a Competitive and Resource Efficient Transport System" [37] a vision of development of the European transport system by 2050 and a strategy of achieving the objectives were presented [38]. According to this document, one of the most important problems of European cities is traffic congestion, bad air condition, and the noise. Reorganising the transportation system in a way which will allow using the multimodality more effectively may diminish negatively its impact on the living environment $[35,39])$. Development of proper infrastructure (park\&ride, kiss\&ride, and urban bike systems) serving individual means of transport (cars, mopeds, and bicycles) in the closest vicinity of the PMR station is also of great importance.

\subsection{The PMR Line as a Part of a Multimodal Transport} System. Effective organisation of urban public transport, especially in metropolitan areas, relates to its full integration and high-quality services. Transportation systems in large cities usually comprise several different modes of transport. Gdańsk is an example of such a situation having bus and tram lines, Tricity Fast Urban Railway and the Pomeranian Metropolitan Railway line, which is the main subject of this article. Full integration of all these modes is difficult as particular modes are owned and managed by different bodies and financed under different regulations. However, when taking the objectives behind constructing the PMR line and high costs of its construction under consideration, cooperation of the bodies responsible for managing and organising the public transportation system shall be the number one priority.

During the period of preparations before launching the Pomeranian Metropolitan Railway the body responsible for managing the urban transportation system in Gdańsk, Zarząd Transportu Miejskiego (Public Transport Council), prepared a plan of necessary changes which should have been introduced to the already existing bus and tram route network. The main assumption of this plan was to reconfigure the routes so they complement each other. It was planned to liquidate the bus lines connecting areas surrounding the PMR stations with the city centre, reorganise ten lines in order to connect them with these stations, and turn them into feeder lines as well as creating a new feeder line. Thanks to these solutions people living in areas remote from the PMR line could access the stations more easily which may result in a larger number of passengers using the public transportation 


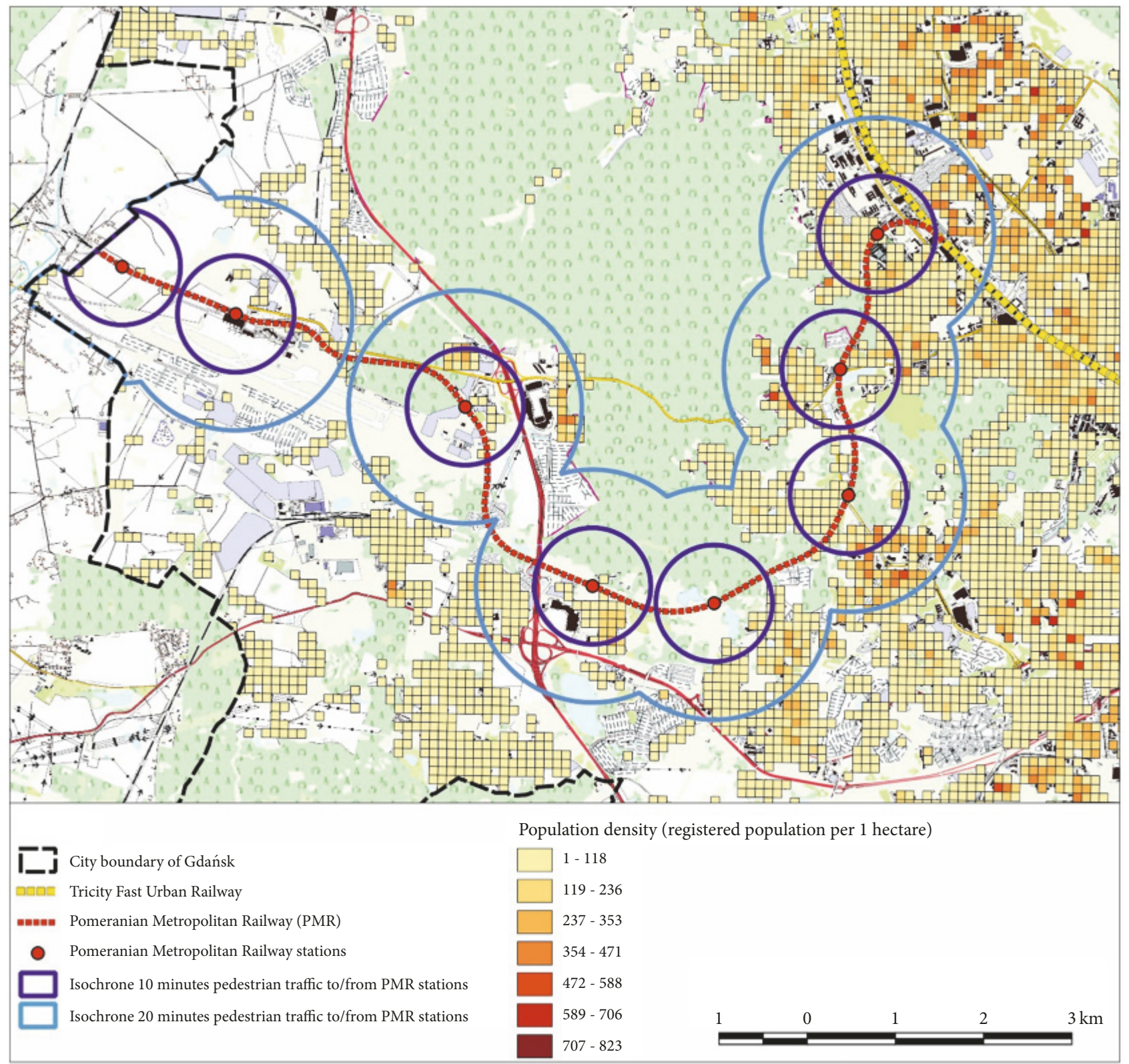

FIgure 5: Population density per 1 ha in the zones of 10 and 20-min walking access to the PMR stations.

system. The main objective of the authorities was to reduce competition between the constructed railway and the existing bus and tram lines. Nonetheless, after launching the PMR line not many changes were introduced to the already existing bus and tram route network. At that time the authorities stated they had to assess the level of the citizens' interest in using the new railway first and then introduce the changes, however, not so rapidly. All in all, it is not an approach fostering the idea of sustainable urban mobility. Obviously, the higher the possibility of a quick and comfortable change, the higher the level of interest in a railway line situated far away from their homes. A multimodal journey may be attractive to the citizens when it is faster than using a single means of transport.
Most of the changes which were actually introduced, when the PMR line was launched, regarded the tram lines as a route extension had been built to Brętowo stop. Thus, a possibility of a door-to-door change between the trams and the PMR trains has been created, especially attractive to the citizens living in Morena housing estate. The extension provides tram services every ten minutes in the rush hours. Some routes of the bus lines have also been modified. There were two integrating hubs constructed near Jasień and Kiepinek stations. The bus stop near Matarnia station has not been liquidated and still two lines stops at it. As for the PMR station located near the airport there were no changes introduced, all three lines stops at it. In Osowa district all the bus lines remained unchanged, too. 


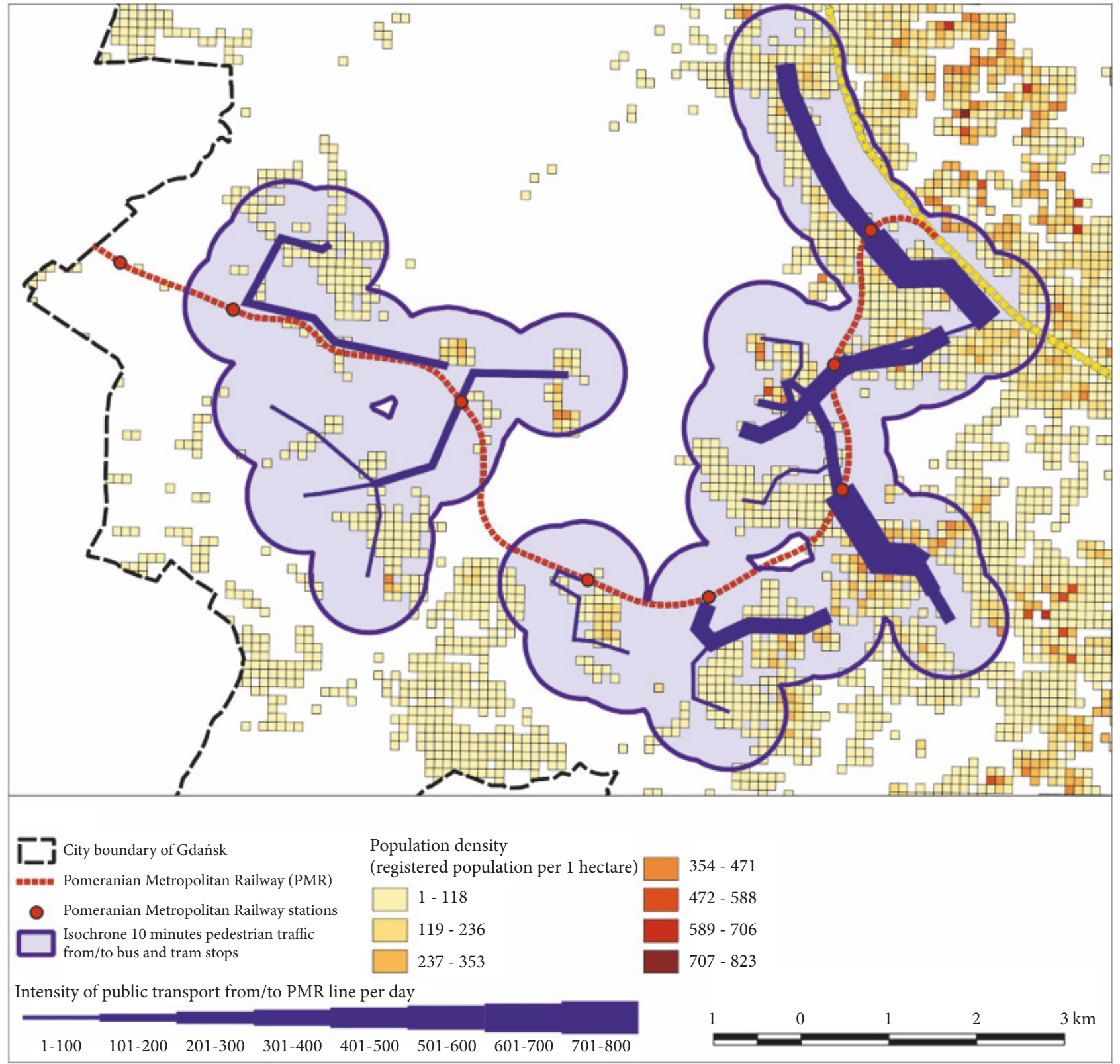

FIGURE 6: Supply of the bus and tram transport services in a multimodal connections model (the number of operations per day).

Launching the Pomeranian Metropolitan Railway line has forced the authorities to reorganise that part of the urban transport system which served the areas surrounding the line. Two integrating hubs (near Kiełpino and Jasien stations) and a tram line extension to Brętowo station were built; all the projects were cofinanced by the European Union. Although these new infrastructural investments were very important for the transportation system of Gdańsk, they did not liquidate the problem of competition between different means of transport. However, the most significant disadvantage of the new transportation system is lack of tariff integration due to different bodies managing the systems. The one and only common metropolitan ticket is distributed by the Metropolitan Public Transport Association of Gdańsk
Bay yet this solution is quite expensive and not popular among the citizens [40].

For the purposes of this study the authors analysed the supply of bus and tram transport services which may be incorporated into multimodal lines to/from the PMR stations (see Figure 6).

Approximately 84 thousand people live within the zone of 10-minute walking accessibility to the nearest bus or tram stop allowing to reach the nearest PMR station in 5 minutes. Figure 6 presents possibilities of change between the PMR stations and the bus/tram stations. Strzyża station has the best accessibility of all as there is a tram line nearby. Because the trams are faster than the buses more citizens can change at this station. Brętowo is another station where 


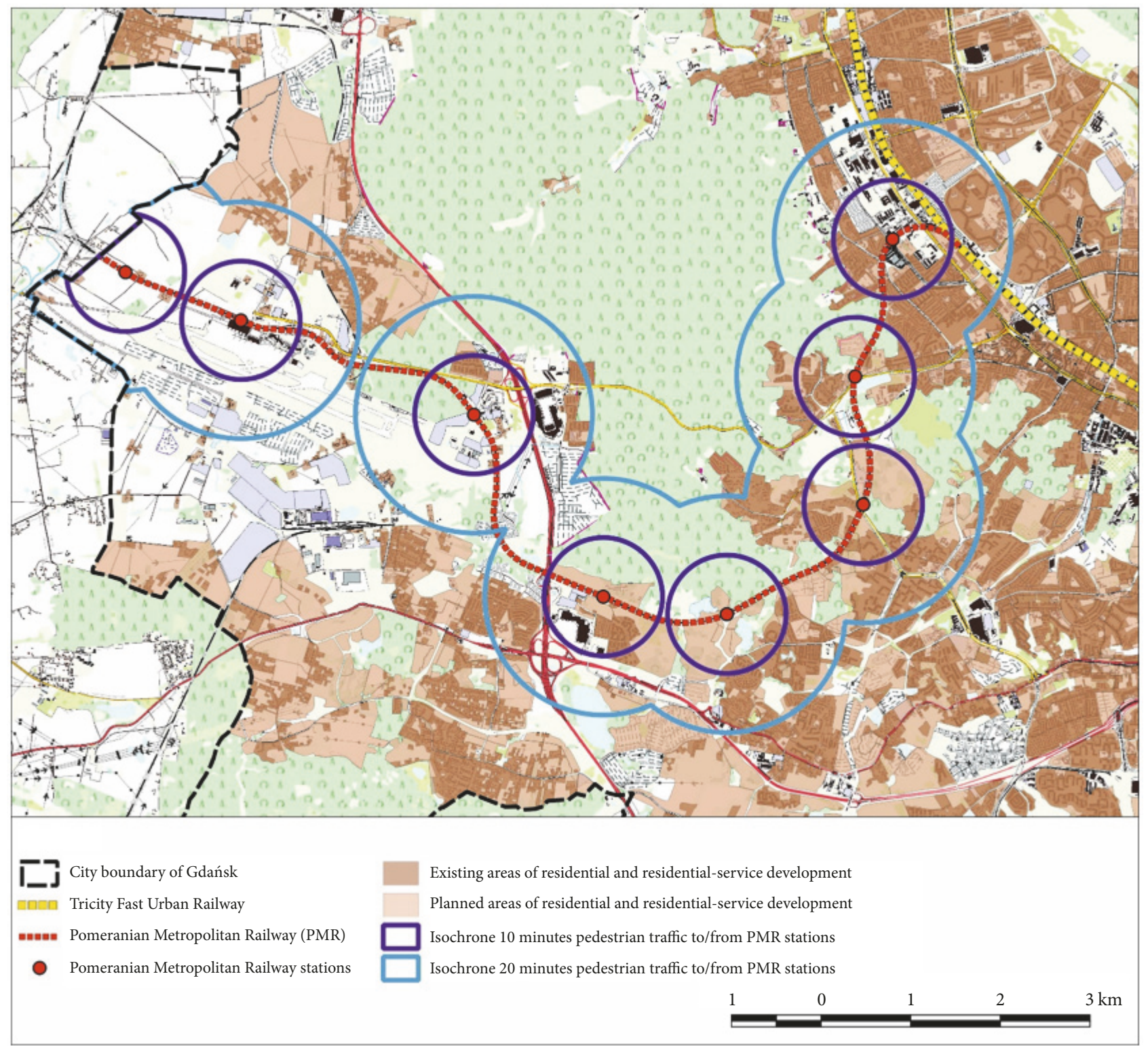

Figure 7: Directions and perspectives for development of different land use forms in the area of 10 and 20 min walking access to the PMR station.

it is possible to organise tram-train services. The supply of transport services has been evaluated as very high, which is essential in the context of population density and type of building development in the PMR impact zone (multifamily buildings, 10-storey block of flats).

The potential of changing the modal split towards the sustainable mobility model can also be assessed by analysing the ways in which passengers get to the PMR station and continue their journey. The survey outcomes indicate that the passengers usually walk to the PMR stations (48\%) (excluding the terminal ones: GdańskWrzeszcz and GdańskOsowa). 16\% of the respondents take a bus, $14 \%$ drive to the stations (both drivers and passengers), and $11 \%$ travel by tram. Such a high percentage of pedestrians, taking the low population density in the areas surrounding the PMR line, indicates the
PMR stations are not well-connected by the means of public transport. As for the percentage of passengers driving to the stations, it seems the PMR directly contributes to reducing the car traffic in the city. Moreover, one can suppose that some of the passengers connecting by bus or tram at the moment used to drive, so the positive effect of the PMR operation is even more visible. It can be also assumed that along with an increasing number of the PMR passengers, which is still rather low, the positive impact of the new railway line will be even stronger and the whole transportation system will follow the path towards the sustainable mobility model.

When analysing the ways in which passengers get to the particular stations some significant differences were observed (Table 2). They result from the land use patterns (functions and intensity of development) and transport 
TABLE 2: Main (over 10\% share) ways of reaching the PMR stations and continuing the journey, based on the results of a survey conducted between 17.10 and 16.11.2017.

\begin{tabular}{|c|c|c|c|c|c|c|}
\hline & on foot & tram & bus & car & train & plane \\
\hline Gdańsk Niedźwiednik & 80,5 & & & & & \\
\hline Gdańsk Kiełpinek & 72,7 & & 10,3 & 13,9 & & \\
\hline Gdańsk Matarnia & 57,8 & & & 22,9 & & \\
\hline Gdańsk Strzyża & 52,0 & 33,0 & & & & \\
\hline Gdańsk Brętowo & 45,4 & 26,2 & 19,2 & & & \\
\hline Gdańsk Port Lotniczy & 43,2 & & & & 10,8 & 30,5 \\
\hline Gdańsk Jasień & 31,8 & & 49,8 & & & \\
\hline Gdańsk Rębiechowo & 9,6 & & & 58,5 & 25,9 & \\
\hline
\end{tabular}

Source: own elaboration based on [21].

linkages between the stations and hubs of the urban public transportation system.

Gdańsk Niedźwiednik station, located relatively near some large housing estates, is used mainly by pedestrians. Moreover, this station is situated so close to the central service district that it may be faster to take a bus or travel by bike (in the rush hours). Kiełpinek and Matarnia stations are also located in densely populated areas and near some large shopping centres. Unlike Niedźwiednik station, these are situated on the upper terrace. That is why it is possible that a significant percentage of passengers coming from peripheral districts of Gdańsk or living outside the city reaches those stations by car and then continues their journey by tram to avoid wasting their time in traffic jams. Strzyża, Brętowo, and Jasien stations are the ones which are reached mainly by trams. As for Port Lotniczy station it is most frequently used by air passengers. Rębiechowo station is located in the outskirts of the city in areas of low population density. This is the reason why the percentage of pedestrians is so low and the percentage of drivers is so high. At this station it is also possible to change the railway line.

4.4. Perspectives for Development of Areas Surrounding the PMR Line. As it has already been mentioned, due to the fact that the PMR line has been constructed along the old railway line, some stations are located too far from the main traffic sources. One of the consequences of such a location is the necessity to change the existing land use patterns of areas surrounding the PMR stations. It is what will, most probably, happen in the future. In the newest version of a general plan for spatial development, which was updated due to launching the PMR line [20], the necessity of pursuing the current spatial policy is emphasized and, at the same time, the document indicates the need to change directions of spatial development of the areas surrounding the stations. The areas used to be earmarked for leisure (green areas) and other extensive functions will be earmarked for the housing and services (Table 3, Figures 7 and 8). It is estimated that the housing function will develop in the closest vicinity of Brętowo, Jasień, Kiełpinek, and Niedźwiednik stations. While any new residential buildings constructed in the districts located on the upper terrace shall not be densely packed up and have a high percentage of the biology active surface, in the case of areas surrounding the PMR stations housing estates will be of higher built-up density. In turn, for the areas surrounding Port Lotniczy and Rębiechowo stations it is planned to liquidate the residential function and intensively develop production, service, and logistic functions. In the vicinity of the airport there will be more than 140 ha earmarked for commercial and public investments [20].

The project assumes further integration of Gdańsk urban transportation system and the transportation system of the whole metropolitan region. Here, the PMR line is also of great importance. According to the adapted in the project classification of integrating hubs, Port Lotniczy station is of national, Wrzeszcz station is of regional, and Rębiechowo is of metropolitan significance. Jasien and Brętowo stations have been classified as local integrating hubs. Other stations shall also have integrating significance. What is more, the question whether a new tram line will be launched along the PMR track connecting Strzyża and Brętowo station is still open or will it be possible in the future to share this section of the PMR track, as current legal regulations do not allow such a solution [20]. Moreover, while electrifying the line, a new station (Gdańsk Firoga) is planned to be built. It could increase accessibility to an office centre being a headquarter of the Gdańsk branch of Intel Corporation.

\section{Conclusions}

During the first decade of political transformation in Poland (after 1989) retrogressive development of public transportation services (road and rail) was observed. At the same time, the role of individual transport (cars) increased significantly. Partially degraded and underdeveloped road infrastructure and the process of urban sprawl in large Polish cities made their citizens face all the negative consequences of living in cities dominated by car traffic.

When Poland became a member of the European Union in 2004 some new opportunities emerged. Financial support of the EU allowed modernising numerous transportation systems although the main focus was put on developing road systems, not railways. In Gdańsk, one of the largest cities in Poland, a completely new, 19,5 km long, railway line was constructed along with eight new stations. Despite the fact that the new line was laid along an old railway track, it was still the greatest undertaking of this type in Poland during the last three decades. 
TABLE 3: Currently dominating and future land-use forms [ha]; changes in the area of residential and service developments within an area of $660 \mathrm{~m}$ radius from the PMR stations in Gdańsk.

Currently dominating land-use forms residential,residential and service development
Future dominating land-use forms -

residentialdevelopment with basic services, residential and service development

\begin{tabular}{lll}
\hline Gdańsk Brętowo & 40,1 & 92,5 \\
\hline Gdańsk Jasień & 14,4 & 55,1 \\
\hline Gdańsk Kiełpienek & 16,6 & 49,6 \\
\hline Gdańsk Niedźwiednik & 27,9 & 56,9 \\
\hline Gdańsk Strzyża & 38,6 & 55,2 \\
\hline Gdańsk Matarnia & 10,9 & 10,7 \\
\hline Gdańsk Port lotniczy & 2,6 & 0,0 \\
\hline Gdańsk Rębiechowo & 3,3 & 0,0 \\
\hline
\end{tabular}

Source: own elaboration based on [20].

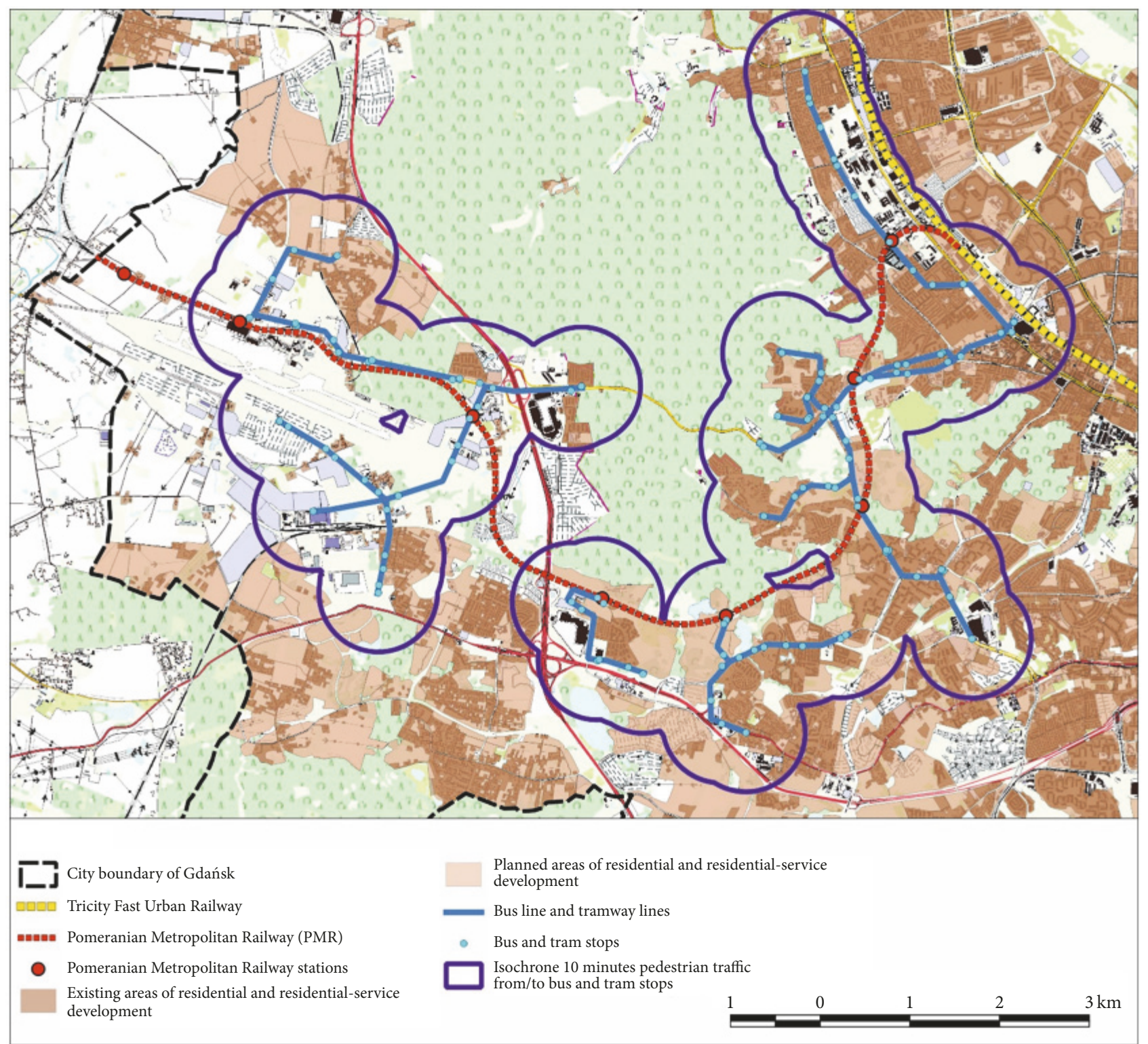

FIGURE 8: Directions and perspectives for development of areas around the PMR line (in the area of bus and tram transport services multimodal connections model). 
The course of the line as well as the stations' location were largely affected by the landscape conditions and already existing infrastructure so there are not many potential passengers in the areas surrounding the PMR line. In 2016 in the zone of 10-minute walking distance to the new stations only 16,2 thousand people lived (population density was $15 \mathrm{ppl} / \mathrm{ha}$ ). In the zone of 20-minute walking distance a total number of residents was 62,8 thousand. However, the number of potential passengers could be higher as there are some public utilities located in close vicinity of the stations: the university campus (Gdańsk Strzyża), large shopping centre (Gdańsk Kiełpinek), industrial and service companies (Gdańsk Matarnia), and the airport and office centre (Gdańsk Port Lotniczy).

As the potential sources of passenger traffic are located far from the line, it was necessary to connect it by the means of public transportation system. Approximately 84 thousand people live within the zone of 10 -minute walking accessibility to the nearest bus or tram stop allowing reaching the nearest PMR station in 5 minutes. However, the plan to connect the PMR line has not been fully implemented. In fact, only $27 \%$ of passengers were getting to the PMR station by bus or tram while $48 \%$ on foot. Thus, it can be stated that in order to increase the passenger traffic on this line, it is necessary to proceed with the integrating actions. The integration shall also comprise the tariff system. Lack of a common ticket tariff hampers introduction of the multimodal model.

Despite the above-mentioned unfavourable conditions, the number of passengers increased from 151,6 thousand in June 2016 to 190,0 thousand in March 2018. Wrzeszcz, Strzyża, and Jasień are the most popular stations among the passengers. Relatively large passenger traffic was also observed at Port Lotniczy and Kiełpinek stations. The least popular station is Niedźwiednik as it is located relatively near the central service district and well-connected by bus.

The PMR line in Gdańsk was planned to serve the airport as well as lower the traffic congestion on roads connecting the upper and lower terraces. In order to increase the number of people travelling by the PMR trains it is not enough to prepare a proper timetable and develop a network of multimodal linkages. Development of the residential function around the PMR stations is also of great importance. In order to do so, it was necessary to introduce some amendments to the general plan of spatial development. The document was adopted in April 2018 and according to its provisions it will be possible to develop an intense residential function in the closest vicinity of the PMR stations. There are three stations around which production, service, and logistic functions will be developed. When observing the ongoing changes on the housing market and some initial projects aimed at developing services and industry sectors around the PMR line, it may be stated that the plan to intensify the residential development in this area has sufficient prospect of success. Hence, the PMR line seems to have a significant impact on the process of urban form transformation.

Taking the main objective of the article into consideration, it has to be stated that launching the PMR has contributed to the changes in the functional and spatial structure of the city, yet to a limited extent. It is mainly because of a relatively short term of its functioning and limited accessibility to the train stops resulting from their peripheral location and the underdeveloped connecting lines system.

Most probably, some passengers do not use the line because the schedule does not match their needs; there is no integrated fee system and the passenger information system is not sufficient. Nonetheless, those issues have not been fully studied in this article so some further research on the passenger exchange and the passengers' motivation behind travelling by train shall be carried in the future.

A relatively short period of the new line operation makes it difficult to formulate any plausible conclusions on time variability. It is especially interesting to what extent the railway line contributes to reducing the car traffic. The analysis of data on the way in which passengers get to the PMR stations provided only superficial conclusions. Any changes introduced to the level of connectivity between the PMR line and the tram/bus system may help to identify the solutions which affect behaviour patterns of the passengers the most. Another interesting issue is the process of adopting new local development plans for areas surrounding the PMR stations as they will set the limits for their spatial development. Analysing strategies adopted by developers who are interested in investing in the areas surrounding the PMR line may also deliver interesting results.

\section{Data Availability}

The data used to support the findings of this study are available from the corresponding author upon request.

\section{Conflicts of Interest}

The authors declare that they have no conflicts of interest.

\section{Acknowledgments}

The authors wish to thank Edyta Damszel-Turek, Marcin Turzyński, and Mateusz Żuk representing the Gdańsk Development Office for sharing cartographic materials used in developing maps presented in this article and Jakub Pietruszewski from Pomeranian Regional Planning Office for sharing results of the research on the Passenger Traffic and Transportation Preferences of the Pomeranian Metropolitan Railway Passengers. The research was partially funded by a grant from the Polish National Science Centre (no. 2016/23/D/HS4/03085).

\section{References}

[1] D. Banister, Ed., Transport and Urban Development, E \& FN SPON. An Imprint of Chapman \& Hall, 2005.

[2] C. Divall and W. Bond, Eds., Suburbanizing the masses: public transport and urban development in historical perspective, Routledge, Routledge, 2003.

[3] P. Rode, G. Floater, N. Thomopoulos et al., "Accessibility in Cities: Transport and Urban Form," in Disrupting Mobility, Lecture Notes in Mobility, pp. 239-273, Springer International Publishing, Cham, 2017. 
[4] E. Glaeser, Triumph of the City: How Our Greatest Invention Makes Us Richer, Smarter, Greener, Healthier, and Happier, Penguin Press, 2011.

[5] P. Jochem, C. Doll, and W. Fichtner, "External costs of electric vehicles," Transportation Research Part D: Transport and Environment, vol. 42, pp. 60-76, 2016.

[6] A. González-Gil, R. Palacin, P. Batty, and J. P. Powell, "A systems approach to reduce urban rail energy consumption," Energy Conversion and Management, vol. 80, pp. 509-524, 2014.

[7] J. Urry, “The 'System' of Automobility," Theory, Culture \& Society, vol. 21, no. 5, pp. 25-39, 2004.

[8] D. Banister, “The sustainable mobility paradigm," Transport Policy, vol. 15, no. 2, pp. 73-80, 2008.

[9] B. Brown and C. Werner, "Before and after a new light rail stop," Journal of the American Planning Association, vol. 75, no. 1, pp. 5-12, 2009.

[10] P. Poudenx, "The effect of transportation policies on energy consumption and greenhouse gas emission from urban passenger transportation," Transportation Research Part A: Policy and Practice, vol. 42, no. 6, pp. 901-909, 2008.

[11] Q. Pan, “The impacts of an urban light rail system on residential property values: A case study of the Houston METRORail transit line," Transportation Planning and Technology, vol. 36, no. 2, pp. 145-169, 2013.

[12] A. D. May, "Integrated transport strategies: a new approach to urban transport policy formulation in the u.k.: foreign summaries," Transport Reviews, vol. 11, no. 3, pp. 223-247, 1991.

[13] Z. Taylor and A. Ciechanski, Foreign Direct Investment in the Polish Transport Sector, Institute of Geography and Spatial Organization. Polish Academy of Sciences, 2013.

[14] Z. Taylor, The Growth and Contraction of the Railway Network in Poland, Institute of Geography and Spatial Organization. Polish Academy of Sciences, 2007.

[15] Transport. Activity results in 2006, Central Statistical Office, 2007.

[16] K. Kajdanek, Społeczno-kulturowe wzory korzystania z systemu transportu $w$ kontekście systemu transport zrównoważonego przykład Wrocławia (Socio-cultural patterns of using the transport system in the context of the sustainable transport system - an example of Wrocław), Wolaniuk, Współczesne czynniki i bariery rozwoju miast: XXVIII Konserwatorium Wiedzy O Mieście (Contemporary factors and barriers to urban development: XXVIII Conservatory of Knowledge about the City), Wydawnictwo Uniwersytetu Łódzkiego, 2016.

[17] T. Komornicki et al., Impact of the construction of motorways and expressways on socio-economic and territorial development of Poland, Ministry of Regional Development, 2013.

[18] E. Raczyńska-Buława, "Agglomeration railway systems in Poland," TTS Technika Transportu Szynowego, vol. 24, pp. 1520, 2017.

[19] E. Babalik, Urban rail systems: a planning framework to increase their success [Ph.D. thesis], Centre for Transport Studies, University of London, 2000.

[20] Study of conditions and directions for the spatial development of the city of Gdansk, Gdańsk Development Office, 2018.

[21] K. Jamroz and J. Jamroz, "Raport z przeprowadzania pomiarów natężenia ruchu pasażerskiego na liniach kolejowych obsługiwanych przez PKP Szybką Kolej Miejską w Trójmieście sp. z o.o. wraz z badaniem preferencji i zachowań komunikacyjnych podróżnych (Report on the measurement of passengertraffic on railway lines served by PKP Szybka Kolej Miejska w Trójmieście sp. Z o.o. together with the study of travelers' preferences and travel behawior)," Fundacja Rozwoju Inżynierii Lądowej, 2017.

[22] ESPON 1.1.1. Potentials for polycentric development in Europe, ESPON Coordination Unit, 2004.

[23] Gdańskie Badania Ruchu 2016 wraz z opracowaniem transportowego modelu symulacyjnego Gdańska, Raport III. Raport $z$ przeprowadzenia badańi pomiarów (Gdańsk Traffic Research 2016 together with the development of Gdan'sk's transport simulation model. Report III. Report on testing and measurements), Urząd Miejski w Gdańsku, 2016.

[24] P. Lorens, "Scenariusze rozwoju przestrzennego obszaru metropolitalnego Trójmiasta," Rozwój Regionalny i Polityka Regionalna, no. 29, p. 71, 2016.

[25] Gdańsk 2030 Plus Strategia Rozwoju Miasta (Gdańsk 2030 Plus City Development Strategy), Urząd Miejski w Gdańsku, 2014.

[26] M. Stępniak and S. Goliszek, "Spatio-Temporal Variation of Accessibility by Public Transport-The Equity Perspective," in The Rise of Big Spatial Data, Lecture Notes in Geoinformation and Cartography, pp. 241-261, Springer International Publishing, Cham, 2017.

[27] K. Fransen, T. Neutens, S. Farber, P. De Maeyer, G. Deruyter, and F. Witlox, "Identifying public transport gaps using timedependent accessibility levels," Journal of Transport Geography, vol. 48, pp. 176-187, 2015.

[28] J. Ritsema van Eck, G. Burghouwt, and M. Dijst, "Lifestyles, spatial configurations and quality of life in daily travel: An explorative simulation study," Journal of Transport Geography, vol. 13, no. 2, pp. 123-134, 2005.

[29] Y. Hadas, "Assessing public transport systems connectivity based on Google Transit data," Journal of Transport Geography, vol. 33, pp. 105-116, 2013.

[30] E. Babalik-Sutcliffe, "Urban rail systems: Analysis of the factors behind success," Transport Reviews, vol. 22, no. 4, pp. 415-447, 2002.

[31] K. Kowalczyk, Pasażerski transport kolejowy na obszarach aglomeracyjnych $w$ Polsce a rozwiązania multimodalne $w$ codziennych dojazdach do pracy (Passenger railway transport in agglomeration areas in Poland and multimodal solutions in everyday commuting) [Ph.D. thesis], Maria Curie-Skłodowska University, Lublin, Poland, 2017.

[32] V. Reis, J. Fabian Meier, G. Pace, and R. Palacin, "Rail and multimodal transport," Research in Transportation Economics, vol. 41, no. 1, pp. 17-30, 2013.

[33] W. B. Jones, C. R. Cassady, and R. O. Bowden, Developing a standard definition of intermodal transportation, Department of Industrial Engineering, Mississippi State University, 2000.

[34] J. Schönharting, A. Schmidt, A. Frank, and S. Bremer, “Towards the multimodal transport of people and freight: Interconnective networks in the RheinRuhr Metropolis," Journal of Transport Geography, vol. 11, no. 3, pp. 193-203, 2003.

[35] S. Krygsman, M. Dijst, and T. Arentze, "Multimodal public transport: An analysis of travel time elements and the interconnectivity ratio," Transport Policy, vol. 11, no. 3, pp. 265-275, 2004.

[36] M. Bąk and J. Burnewicz, Challenges for multimodal passenger transport, Szyliowicz. Multimodal Transport Security Frameworks and Policy Applications in Freight and Passenger Transport, Comparitive Perspectives on Transportation Security, Edward Elgar Publishing, 2016.

[37] White paper, Roadmap to a Single European Transport Area Towards a competitive and resource efficient trandsport system, European Commission, 2011. 
[38] T. Dyr, "Europejska polityka transportowa na pierwszą połowę XXI wieku (European transport policy for the first half of the 21st century)," Autobusy-Technika, Eksploatacja, Systemy Transportowe, vol. 12, no. 10, pp. 20-29, 2011.

[39] L. Bertolini and F. le Clercq, "Urban development without more mobility by car? Lessons from Amsterdam, a multimodal urban region," Environment and Planning A, vol. 35, no. 4, pp. 575-589, 2003.

[40] M. Połom, "Disintegration of the public transport services in the Gdańsk agglomeration," Metropolitan. Przeglad Naukowy, vol. 8 , no. 2 , pp. $70-81$. 


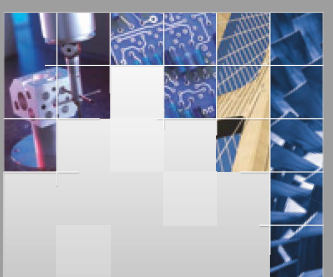

\section{Enfincering}
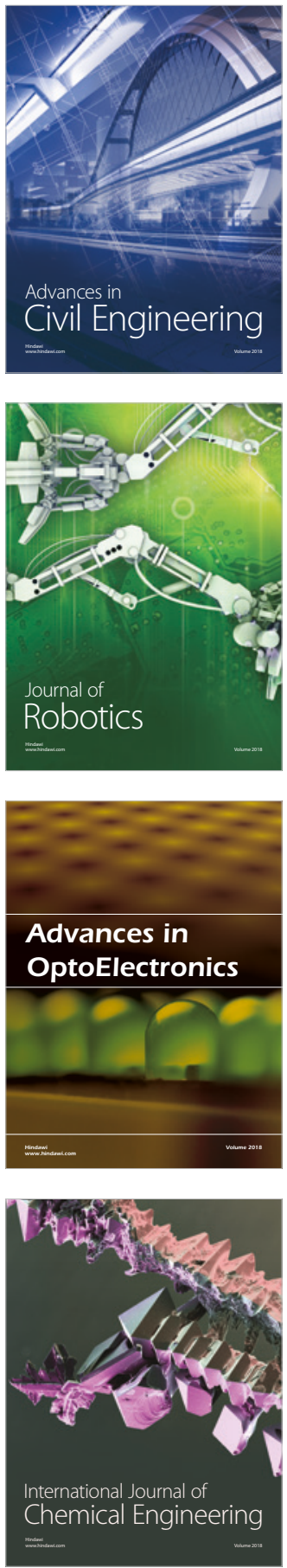

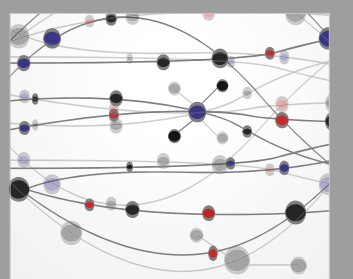

\section{Rotating \\ Machinery}

The Scientific World Journal

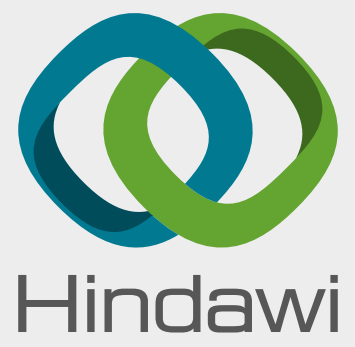

Submit your manuscripts at

www.hindawi.com
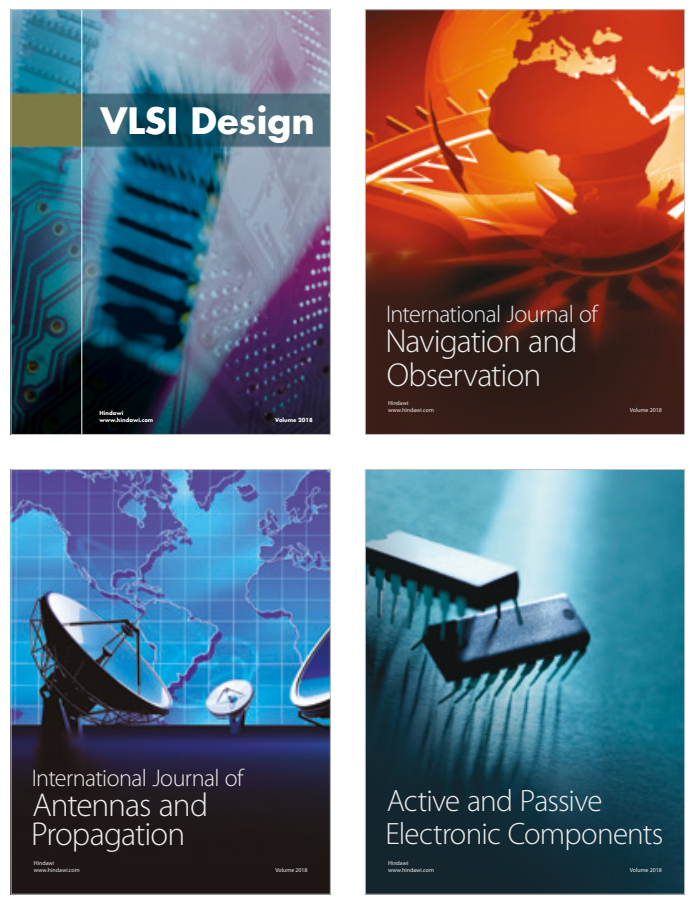
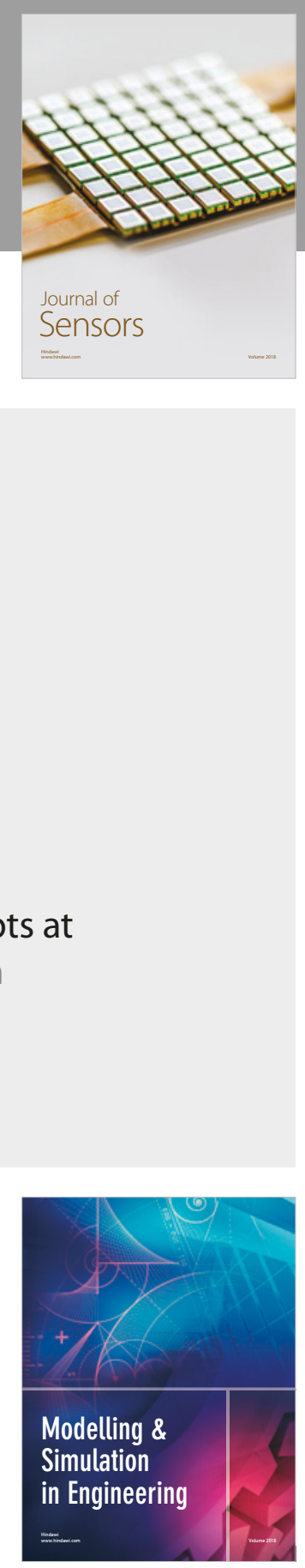

\section{Advances \\ Multimedia}
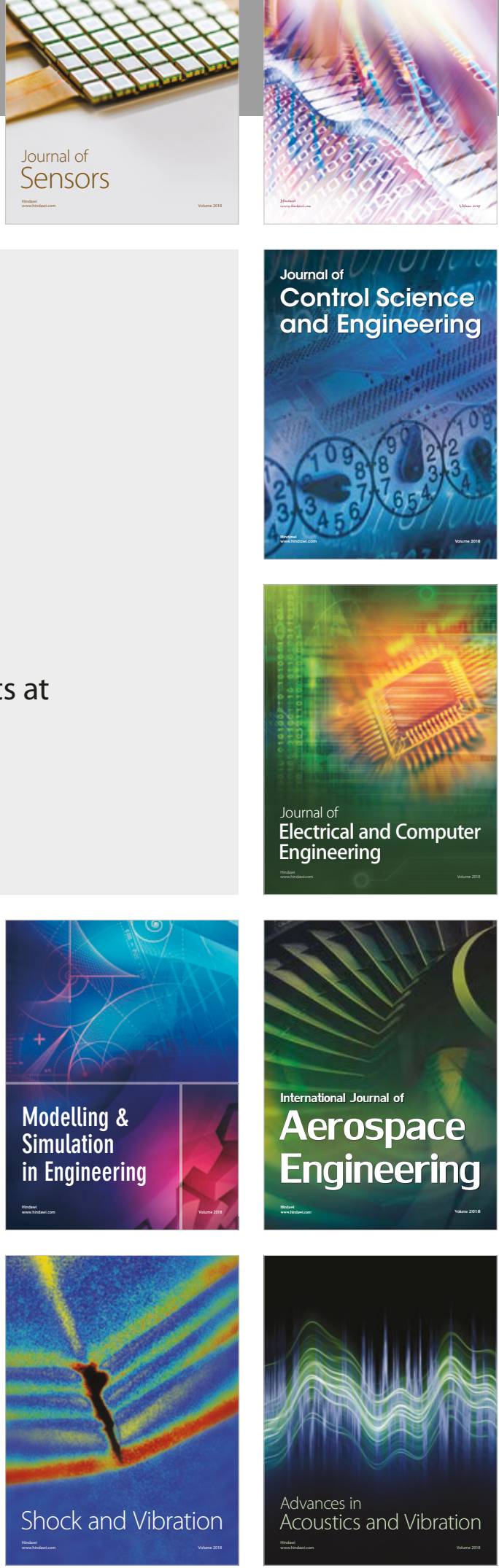